\title{
COMPARATIVE STUDY OF RESIDUAL STRESS PREDICTION METHODS IN ADDITIVE MANUFACTURING PROCESSES
}

Suyambazhahan Sivalingam ${ }^{1, *}$, Sunny Narayan², Sakthivel Rajamohan ${ }^{3}$, Ivan Grujic ${ }^{4}$, Nadica Stojanovic ${ }^{4}$

${ }^{1}$ Department of Mechanical Engineering, School of Mechanical, Chemical, and Materials Engineering, Adama Science and Technology University, Adama, Ethiopia

${ }^{2}$ Mechanical Engineering Department, Qassim University, Burydah, Saudi Arabia

${ }^{3}$ Amrita School of Engineering, Amrita Vishwa Vidyapeetham, Coimbatore, Tamilnadu, India

${ }^{4}$ Motor Vehicle Engineering Department, University of Kragujevac, Serbia

*E-mail of corresponding author: suyamiitm@gmail.com

\section{Resume}

The additive manufacturing (AM) of products involves various processes, such as raising the temperature of a work-piece (part) and substrate to the melting point and subsequent solidification, using a movable source of heat. The work piece is subjected to repeated cycles of heating and cooling. The main objective of this work was to present an overview of the various methods used for prediction of the residual stresses and how their contributions can be used to improve current additive manufacturing methods. These novel methods of manufacturing have several merits, compared to conventional methods. Some of these merits include the lower costs, higher precision and accuracy of manufacturing, faster processing time and more eco-friendly approaches to processes involved.

Available online: https://doi.org/10.26552/com.C.2022.2.B99-B105

\section{Article info}

Received 14 March 2021

Accepted 26 July 2021

Online 2 December 2021

\section{Keywords:}

additive manufacturing

3-D printing

residual stresses

ANSYS

FLUENT

laser melting

\section{Introduction}

Additive manufacturing (AM), also known as the 3D printing, involves building components layer by layer. It includes various processes, such as melting by laser beam, beam melting of electrons, laser cladding and powder deposition methods [1]. Due to the higher levels of thermal stresses and strains involved and higher residual stresses are present in a work piece manufactured using AM. The residual stresses in manufactured components have been analyzed using various analytical, computational and experimental methods. Experimental methods have involved hole drilling process, layer removal, sectioning, X-ray diffraction, as well as various magnetic and ultrasonic methods [1]. Hodge et al. predicted residual stress concentration during the selective laser melting (SLM) method, using various models of heat transfer and solid mechanics [2]. Li et al. presented case studies on residual stress and distortion of the L-shaped bar and the bridge structure via the deposition scalability and validation with the experimental data [3]. They proposed three new methods, based on the heat source, layer and hatching models. Santos et al. described the porosity due to the laser sintering for thermomechanical simulation [4]. Zhang et al. have used neuron fuzzy interface systems (NFIS) for prediction of residual stresses in aluminum components of the aircraft industry [5]. Chukwujekwu et al. predicted residual stresses on a $6 \mathrm{Al}-4 \mathrm{~V}$ titanium-based work-piece, using finite element analysis [6]. Meyghani et. Al. undertook a comparative study of results obtained from ABAQUS, ANSYS and FLUENT-based simulations for the friction stir welding [7]. Kortabarri et al. compared stress concentration in an Inconel 718-based work piece [8]. Mukherjee et al. found that stresses can be controlled by decreasing the thickness of the substrate material layer during the AM [9]. Huang et al. proposed a model for prediction of residual stresses in orthogonal cutting processes [10]. Yang et al. studied residual stresses produced during the laser bed fusion processes [11].

While analyzing the residual stress levels, it is important to consider the thermal as well as mechanical properties of materials. Megahed et al. demonstrated the effects of the gas bubbles entrapment in nickel super alloy, as shown in Figure 1 [12]. There are different methods available for the manufacturing process and it is essential to identify the best method with the least impact to the product for low thermal residual stresses. Therefore, the present study is focused on identifying the best method for predicting the residual stresses in AM. 


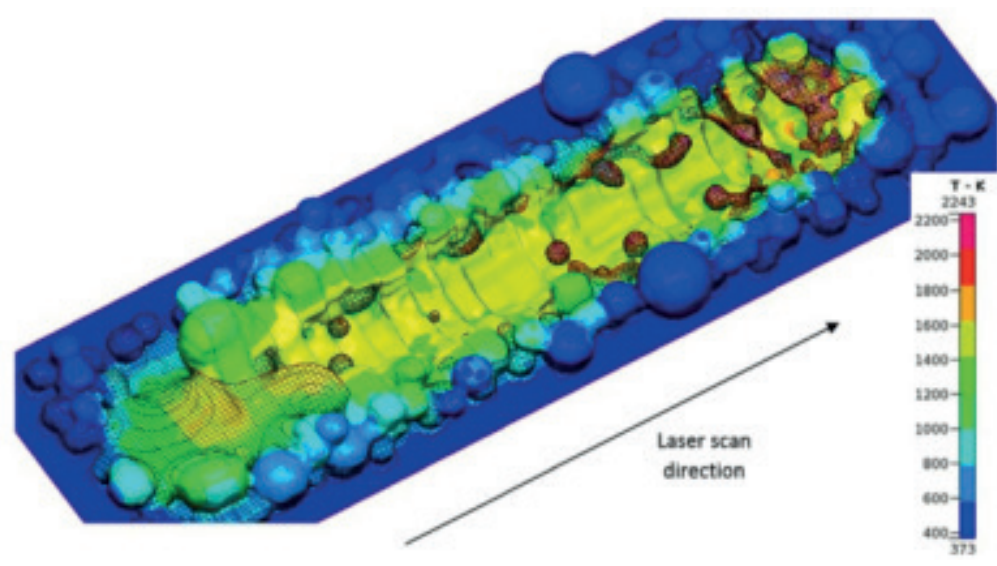

Figure 1 Bubble entrapment in nickel alloy work-piece [12]

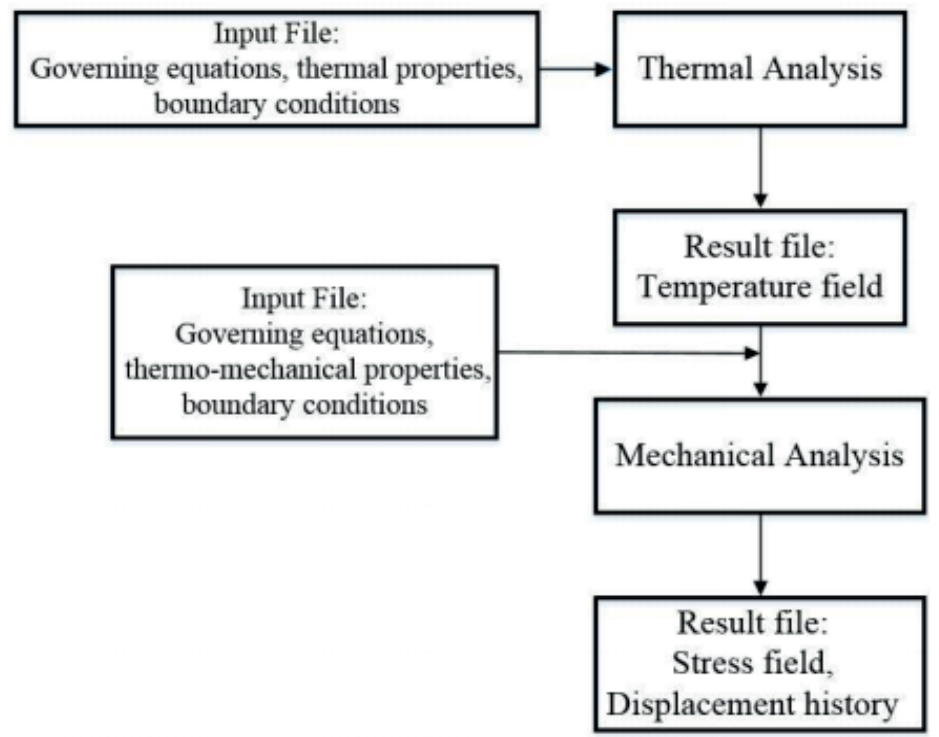

Figure 2 Flow chart for numerical prediction of residual stress levels [28]

\section{Literature review}

Additive manufacturing (AM) has wide applications for fabrication of metal parts in a variety of industries [13-14]. The AM technologies enable making of complex geometry using gradually adding thin layers of metals [15]. Powder bed fusion (PBF) and directed energy deposition (DED) are two methods widely used for AM. In PBF, high beam of energy is used to melt layers of metal powders in vacuum atmosphere. The DED produces parts by melting feed stock material through direct feeding powder or feeding wire [16-19]. Other processes like binder jetting or metal FDM (fused deposition modeling) utilize a binder agent [20]. Residual stress caused by the thermal cycle in AM is a critical issue for the manufactured parts [21-22]. Decreasing temperature gradient by preheating the feed material or the substrate is the most used approach to reduce the residual stress [22-27]. Figure 2 shows an ABAQUSbased algorithm, presented by Liu et al. to simulate the residual stresses developed. The work-piece used for their study was a cantilever, in which metal deposition was made at the middle of the beam [28]. Figure 3 shows the contour plots of normal and Von Mises stresses developed in the work-piece. It can be seen that compressive stresses were developed on the free surface of a structure, due to the higher temperature gradient. The residual stresses at the bottom layer were tensile in nature, due to the cooling of molten metal layers.

Figure 4 shows a comparison of results of simulated and experimental residual stress levels of a Ti64 workpiece, fabricated using a blown powder process. Good coherence between the two results can be seen.

Figure 5 illustrates that higher levels of stresses were found in a heat affected zone of $200 \mu \mathrm{m}$ along the width and depth of a sample. The stresses were initially tensile in nature and, later on, changed to compressive before reducing to zero levels.

Based on the temperature method, maximum tensile stress was found on the top layer of the work-piece (part) and decreased with depth of a part, as shown in Figure 6. A sudden change in the nature of residual stresses was observed, from tensile in the work-piece to compressive in the substrate. 


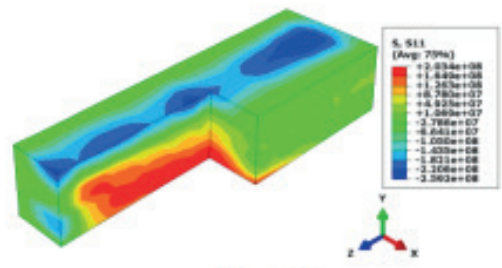

(a) $\sigma 11$

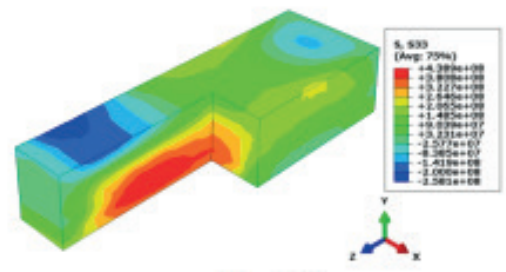

(c) $\sigma 33$

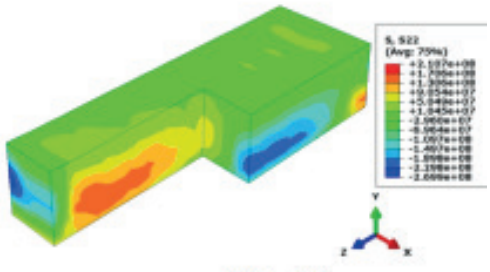

(b) $\sigma_{22}$

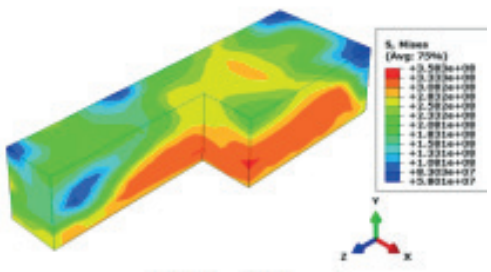

(d) Von Mises stress

Figure 3 Contour plots of residual stresses [28]

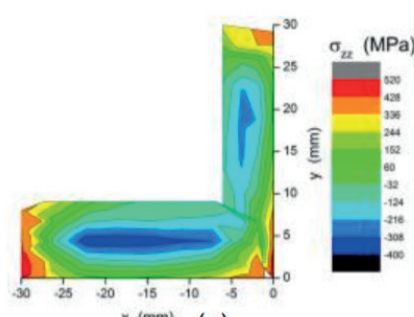

(a)

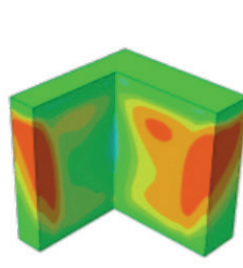

(b)

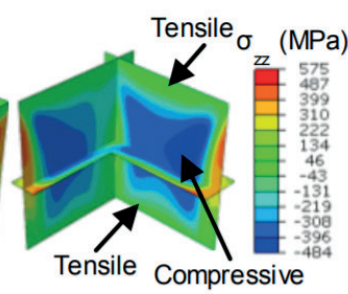

Figure 4 Comparison of simulated and experimental residual stress levels of Ti64 work-piece [28]

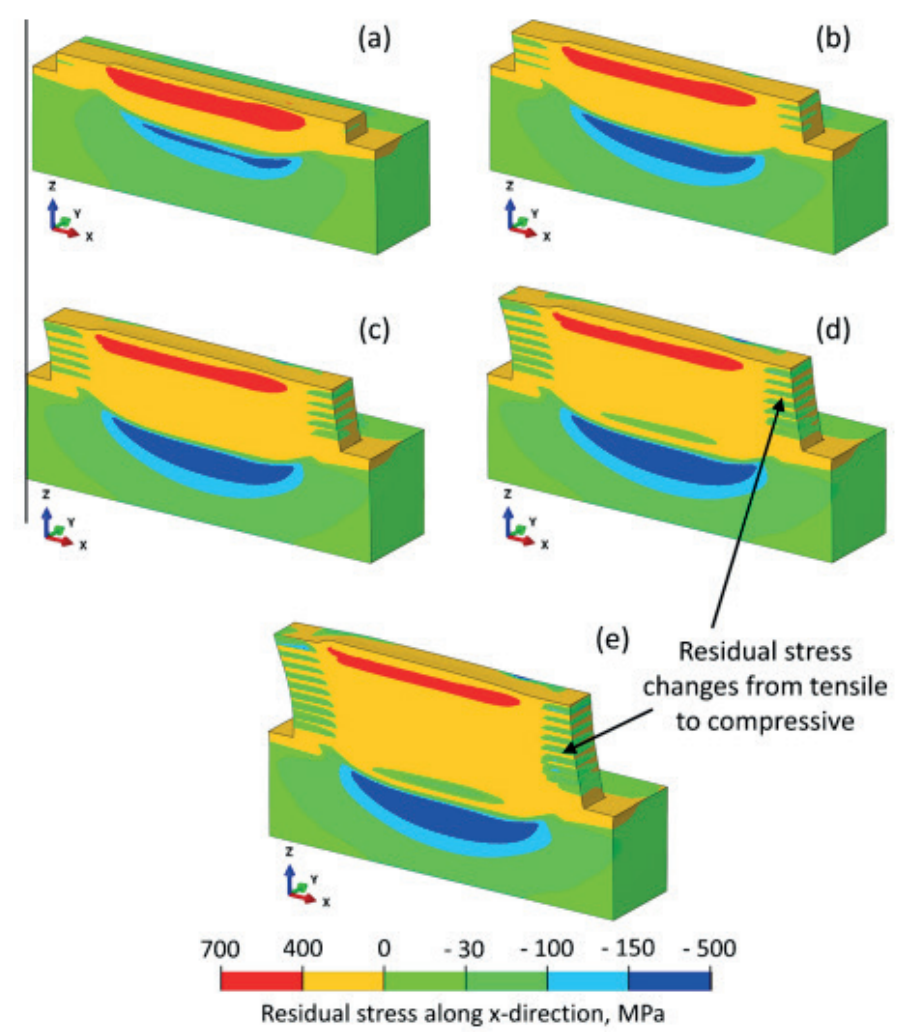

Figure 5 End of the $2^{\text {nd }}$ layer deposition (b) End of the $4^{\text {th }}$ layer deposition (c) End of the $6^{\text {th }}$ layer deposition (d)End of the $8^{\text {th }}$ layer deposition and (e) End of the $10^{\text {th }}$ layer deposition [28] 

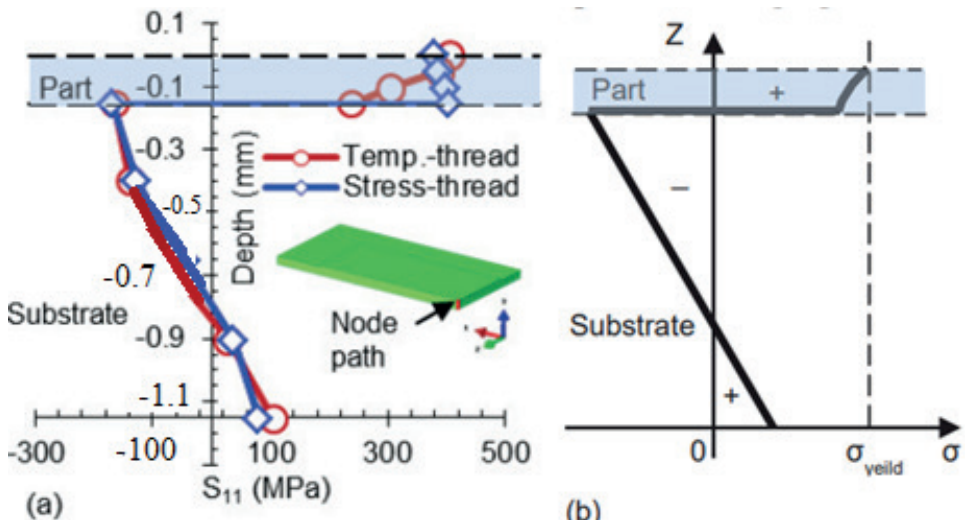

(b)

Figure 6 Temperature and stress distribution during the laser melting process [28]

Table 1 Residual stress measurement techniques in metal AM [29]

\begin{tabular}{ccccc}
\hline Method & Penetration & Resolution & Accuracy & Cost \\
\hline Hole Drilling & Size of hole & $50-100 \mu \mathrm{m}$ depth & $\pm 50 \mathrm{MPa}$ & Low \\
Curvature & 0.1 to 0.5 thickness & & Minimum & Medium \\
X ray diffraction & Near surface & $1 \mathrm{~mm}$ & $\pm 20 \mathrm{MPa}$ & High \\
Neutron diffraction & Volumetric & $500 \mu \mathrm{m}$ & $\pm 40 \times 10^{-6}$ & High \\
\hline
\end{tabular}

\section{Sources of residual stress in AM}

\subsection{Residual stress model}

Mercelis et al. studied the temperature gradient mechanism (TGM) model [23]. In this model, high energy source heats up the feed material rapidly, which expands in a restrained way leading to compressive stresses. During the cooling stage, as the heat source is removed, the cooling causes a shrinkage restrained by the plastic strain. Finally, the tensile residual stress in the heated zone balances compressive zone.

\subsection{Stress types and measurement}

Residual stresses are of following types: type I, type II and type III [29]. Type I stresses are at the macro level. Type II stresses are on microscale stress due to anisotropic properties and type III stress is on a nanoscale due to coherency and dislocation [29]. Type II and type III residual stresses have very limited effect.

Table 1 summarizes the major residual stress measurement methods. The most widely applied nondestructive methods in $\mathrm{AM}$ are the $\mathrm{X}$-ray and neutron diffraction methods [29].

\subsection{Features of residual stresses}

Oliveira et al. studied features of residual stresses in Cobalt based laser deposited claddings [30]. Rangaswamy et al. investigated the residual stress of SS 316L and Inconel 718 parts using the neutron diffraction method [31]. The residual stress at the center of samples was compressive in nature. Tensile residual stresses were observed at the edges. The magnitudes of these stresses were $50 \%-60 \%$ of the yield strength. Denlinger et al. investigated the effects of dwell time on the residual stress for the DED processed Ti64 and Inconel 625 samples [32]. Those two materials showed opposite trends, wherein by increase of cooling time generated lower residual stress for Inconel 625 samples. On the other hand, reducing the cooling time for Ti64 samples resulted in much lower level of residual stress [32].

\subsection{Control of stress}

Various methods to control stresses include the feedback control, control of thermal gradient, control of scanning and motion-based control. The feedback control involves a change to homogenize the temperature distribution [33]. Mechanical method involves balancing of tensile stresses by introduction of compressive pressure by shock peening or rolling [34]. Preheating of substrate or powder bed is used to reduce residual stress and produce crack-free components. The postheating treatment process like annealing is used to homogenize the microstructure and tailoring of mechanical properties.

\section{Summary and outlook}

This paper gives an overview of the residual stress in the metal AM. The residual stress formation mechanism has been proposed and its impact was 
discussed. The measurement methods of residual stress and its relationship with microstructure were then analyzed. The typical residual stress characteristics and its mitigation methods for the metal AM were summarized and discussed. Key findings of this work are summarized as follows:

- Residual stress formation in the metal AM is mainly caused by high temperature gradient and rapid cooling illustrated by the proposed new model.

- High tensile residual stress is very typical in the surface zone for the metal AM, while the presence of substrate has a significant influence on residual stress magnitudes.

- Residual stress in the metal AM could be mitigated through in-process methods (e.g. preheating, process planning, feedback control, laser peening) and post-process methods (e.g. machining and heat treatment, which is the most effective method for relief of residual stress).

Current study on residual stress in $\mathrm{AM}$ is in the nascent stage, future research directions remain to be explored to include measurement methods for macro/ micro residual stresses, crystal structure, simulation, in-process and post- process mitigation and the impacts on part dimensional accuracy and functionality, such as fatigue, creep and corrosion.

\section{Conclusions}

A comparative analysis of the various methods for predicting the residual stresses in AM processes was undertaken in the present study. The presence of residual stresses in manufactured parts presents a challenge to the many benefits of AM techniques. In this work, different methods to predict the distribution of residual stresses have been presented. From the results, it is concluded that the finite element analysis-based techniques are more effective ways than other methods for analyzing the thermal stresses. The presented results can be used as sources to optimize the heat flux and thickness of layers in parts fabricated using AM methods, so that residual stress levels are kept at their minimum.

\section{References}

[1] What is additive manufacturing? - GE Additive [online]. Available from: https://www.ge.com/additive/additivemanufacturing

[2] HODGE, N. E., FERENCZ, R. M.,VIGNES, R. M. Experimental comparison of residual stresses for a thermo mechanical model for the simulation of selective laser melting. Additive Manufacturing [online]. 2016, 12(B), p. 159-168. ISSN 2214-8604. Available from: https://doi.org/10.1016/j.addma.2016.05.011

[3] KELLER, N., PLOSHIKHIN, V. New method for fast predictions of residual stress and distortion of am parts [online]. 2015. Available from: https://sffsymposium.engr.utexas.edu/sites/default/files/2014-096Keller.pdf

[4] SANTOS, L. S., GUPTA, S. K., BRUCK, H. A. Simulation of buckling of internal features during selective laser sintering of metals. Additive Manufacturing [online]. 2018, 23, p. 235-245. ISSN 2214-8604. Available from: https://doi.org/10.1016/j.addma.2018.08.002

[5] ZHANG, X. H., AN, Q. L., CHEN, M. Residual stress prediction by adaptive neuro-fuzzy system in milling aluminum alloy. Key Engineering Materials [online]. 2008, 392-394, p. 504-508. ISSN 1662-9795. Available from: https://doi.org/10.4028/www.scientific.net/KEM.392-394.504

[6] Third Wave [online]. Available from: https://hirdwavesys.com/wp-content/uploads/2014/06/fem-sim-of-rstresses-in-machining-titanium.pdf

[7] MEYGHANI, B., AWANG, M., EMAMIAN, S. A comparative study of finite element analysis for friction stir welding application. APRN Journal of Engineering and Applied Sciences. 2016, 11(22), p. 12984-12989. ISSN 1819-6608.

[8] KORTABARRI, A., MADARIAG, A., FERNANDEZ, E., ESNAOL, J. A., ARRAZOLA, P. J. A comparative study of residual stress profiles on Inconel 718 induced by dry face turning. Procedia Engineering [online]. 2018, 19, p. 228-234. ISSN 1877-7058. Available from: https://doi.org/10.1016/j.proeng.2011.11.105

[9] MUKHERJEE, T., ZHANG, W., DEBROY., T. An improved prediction of residual stresses and distortion in additive manufacturing. Computational Materials Science [online]. 2017, 126, p. 360-372. ISSN 0927-0256. Available from: https://doi.org/10.1016/j.commatsci.2016.10.003

[10] HUANG, X.-D., ZHANG, X.-M., LEOPOLD, J., DING, H. Analytical model for prediction of residual stress in dynamic orthogonal cutting process. Journal of Manufacturing Science and Engineering [online]. 2017, 140(1), 011002. ISSN 1087-1357, eISSN 1528-8935. Available from: https://doi.org/10.1115/1.4037424

[11]YANG, Y. P., JAMSHIDINIA, M., BOULWARE, P. Prediction of microstructure, residual stress and deformation in laser powder bed fusion process. Computational Mechanics [online]. 2017, 61, p. 599-615. ISSN 0178-7675, eISSN 1432-0924. Available from: https://doi.org/10.1007/s00466-017-1528-7 
[12] MEGAHED, M., MINDT, H.-W., N'DRI, N., DUAN, H., DESMAISON, O. Metal additive-manufacturing process and residual stress modeling. Integrating Materials and Manufacturing Innovation [online]. 2016, 5, p. 61-93. ISSN 2193-9764, eISSN 2193-9772. Available from: https://doi.org/10.1186/s40192-016-0047-2

[13] LEVY, G. N., SCHINDEL, R., KRUTH, J. Rapid manufacturing and rapid tooling with layer manufacturing (LM) technologies, state of the art and future perspectives. CIRP Annuals - Manufacturing Technology. 2003, 52(2), p. 589-609. ISSN 0007-8506.

[14] DEBROY, T., WEI, H. L., ZUBACK, J. S., MUKHERJEE, T., ELMER, J. W., MILEWSKI, J. O., BEESE, A. M., WILSON-HEID, A., DE, A., ZHANG. W. Additive manufacturing of metallic components - process, structure and properties. Progress in Materials Science [online]. 2018, 92, p. 112-224. ISSN 0079-6425. Available from: https:// doi.org/10.1016/j.pmatsci.2017.10.001

[15] KRUTH, J., LEU, M., NAKAGAWA, T. Progress in additive manufacturing and rapid prototyping. CIRP Annuals - Manufacturing Technology. 1998, 47(2), p. 525-540. ISSN 0007-8506.

[16] MEINERS, W., WISSENBACH, K., GASSER, A. Shaped body especially prototype or replacement part production. DE Patent, 1998.

[17] FRAZIER, W. E. Metal additive manufacturing: a review. Journal of Materials Engineering and Performance [online]. 2014, 23(6), p. 1917-1928. ISSN 1059-9495. Available from: https://doi.org/10.1007/s11665-014-0958-z

[18] MURR, L. E., GAYTAN, S. M., RAMIREZ, D. A., MARTINEZ, E., HERNANDEZ, J., AMATO, K. N., SHINDO, P. W., MEDINA, F. R., WICKER, R. B. Metal fabrication by additive manufacturing using laser and electron beam melting technologies. Journal of Material Science and Technology [online]. 2012, 28(1), p. 1-14. ISSN 10050302. Available from: https://doi.org/10.1016/S1005-0302(12)60016-4

[19] GIBSON, I., ROSEN, D., STUCKER, B. Additive manufacturing technologies. Berlin: Springer; 2010. ISBN 9781-4939-2113-3.

[20] FLYNN, J. M., SHOKRANI, A., NEWMAN, S. T., DHOKIA, V. Hybrid additive and subtractive machine tools research and industrial developments. International Journal of Machine Tools and Manufacture [online]. 2016, 101, p. 79-101. ISSN 0890-6955. Available from: http://dx.doi.org/10.1016/j.ijmachtools.2015.11.007

[21] MIRELES, J., KIM, H., LEE, I. H., ESPALIN, D., MEDINA, F., MACDONALD, E., WICKER, R. Development of a fused deposition modeling system for low melting temperature metal alloys. Journal of Electronic Packaging [online]. 2013, 135(1), p. 011008. ISSN 1043-7398, eISSN 1528-9044. Available from: https://doi. org/10.1115/1.4007160

[22] SHIOMI, M., OSAKADA, K., NAKAMURA, K., YAMASHITA, T., ABE, F. Residual stress within metallic model made by selective laser melting process. CIRP Annuals - Manufacturing Technology. 2004, 53(1), p. 195-198. ISSN 0007-8506.

[23] MERCELIS, P., KRUTH, J. Residual stresses in selective laser sintering and selective laser melting. Rapid Prototyping Journal [online]. 2006, 12(5), p. 254-265. ISSN 1355-2546. Available from: https://doi. org/10.1108/13552540610707013

[24] BUCHBINDER, D., MEINERS, W., PIRCH, N., WISSENBACH, K., SCHRAGE, J. Investigation on reducing distortion by preheating during manufacture of aluminum components using selective laser melting. Journal of Laser Applications [online]. 2014, 26(1), 012004. eISSN 1938-1387. Available from: https://doi. org/10.2351/1.4828755

[25] ZAEH, M. F., BRANNER, G. Investigations on residual stresses and deformations in selective laser melting. Production Engineering [online]. 2010, 4(1), p. 35-45. ISSN 0944-6524, eISSN 1863-7353. Available from: https:// doi.org/10.1007/s11740-009-0192-y

[26] VILARO, T., COLIN, C., BARTOUT, J. As-fabricated and heat-treated microstructures of the Ti-6Al-4V alloy processed by selective laser melting. Metallurgy Material Transactions A [online]. 2011, 42(10), p. 3190-3199. ISSN 1073-5623. Available from: https://doi.org/10.1007/s11661-011-0731-y

[27] KRUTH, J., DECKERS, J., YASA, E., WAUTHLER, R. Assessing and comparing influencing factors of residual stresses in selective laser melting using a novel analysis method. Proceedings of Institute of Mechanical Engineers Part B: Journal of Engineering Manufacturing [online]. 2012, 226(6), p. 980-991. ISSN 0954-4054, eISSN 2041-2975. Available from: https://doi.org/10.1177/0954405412437085

[28] LI, C., LIU, J., GUO, Y. Prediction of residual stress and part distortion in selective laser melting. Procedia CIRP [online]. 2016, 45, p. 171-174. ISSN 2212-8271. Available from: https://doi.org/10.1016/j.procir.2016.02.058

[29] WITHERS, P., BHADESHIA, H. Residual stress. Part 1 - measurement techniques. Materials Science and Technology [online]. 2001, 17(4), p. 355-365. ISSN 0267-0836, eISSN 1743-2847. Available from: https://doi. org/10.1179/026708301101509980

[30] OLIVEIRA, U., OCELÍK, V., DE HOSSON, J. T. M. Residual stress analysis in co- based laser clad layers by laboratory X-rays and synchrotron diffraction techniques. Surface and Coatings Technology [online]. 2006, 201(34), p. 533-542. ISSN 0257-8972. Available from: https://doi.org/10.1016/j.surfcoat.2005.12.011 
[31] RANGASWAMY, P., GRIFFITH, M., PRIME, M., HOLDEN, T., ROGGE, R., EDWARDS, J., SEBRING, R. Residual stresses in LENS® components using neutron diffraction and contour method. Materials Science and Engineering: A [online]. 2005, 399(1-2), p. 72-83. ISSN 0921-5093. Available from: https://doi.org/10.1016/j. msea.2005.02.019

[32] DENLINGER, E. R., HEIGEL, J. C., MICHALERIS, P., PALMER, T. A. Effect of inter - layer dwell time on distortion and residual stress in additive manufacturing of titanium and nickel alloys. Journal of Materials Processing Technology [online]. 2015, 215, p. 123-131. ISSN 0924-0136. Available from: https://doi.org/10.1016/j. jmatprotec.2014.07.030

[33] TAMMAS-WILLIAMS, S., ZHAO, H., LEONARD, F., DERGUTI, F., TODD, I., PRANGNELL, P. XCT analysis of the influence of melt strategies on defect population in Ti-6Al-4V components manufactured by selective electron beam melting. Materials Characterization [online]. 2015, 102, p. 47-61. ISSN 1044-5803. Available from: https:// doi.org/10.1016/j.matchar.2015.02.008

[34] BRINKSMEIER, E., LEVY, G., MEYER, D., SPIERINGS, A. Surface integrity of selective-laser-melted components. CIRP Annuals - Manufacturing Technology [online]. 2010, 59(1), p. 601-606. ISSN 0007-8506. 